\title{
Apparent glacially induced structural controls on limestone conduit development in Ohio Caverns, United States
}

\author{
Adrienne Watts* and Ira D. Sasowsky \\ Department of Geosciences, University of Akron, Akron, OH 44235, USA
}

\begin{abstract}
Rock discontinuities such as bedding planes and joints are important controls on the form that caves take. We examined structural controls on the development of Ohio Caverns. The cave formed in Devonian limestone underlying a small bedrock knob (Mt. Tabor) within the Interior Lowland province, United States. The area has been overridden by continental glaciation multiple times. The bedrock is pervasively fractured, with many curved and wavy near-vertical fractures showing many different orientations. In the case of Ohio Caverns, it appears that the controlling fractures in map view may not be joints sensu stricto, but rather some combination of tensile and shear (mode-1 and mode-2) fractures, probably forming in the regime transition between tensile and shear fracturing. This is easy to envision in a situation with ice advancing over this topographic high, and would result in the curved fractures that are observed in many places in the cave. It can also explain the numerous fracture directions. However, not all fractures are conduit-significant. The cave initiated on or near a single bedding plane, and the cave passages exhibit strong keyhole or plus-sign cross sections. Passage and fracture orientations are inconsistent with regionally expected directions. It is likely that mechanical, hydraulic, and thermal stresses related to glaciation caused the fracturing in Mt. Tabor. The cave then developed on this template according to local hydrologic conditions. This presents a newly documented structural template sub-type for cave development.
\end{abstract}

Keywords: fractures; Ohio; glacial; thermal; speleogenesis

Received 20 January 2014; Revised 12 December 2015; Accepted 13 December 2015

Citation: Watts A. and Sasowsky I.D., 2016. Apparent glacially induced structural controls on limestone conduit development in Ohio Caverns, United States. International Journal of Speleology, 45 (1), 59-69. Tampa, FL (USA) ISSN 0392-6672 http://dx.doi.org/10.5038/1827-806X.45.1.1821

\section{INTRODUCTION}

The overall form that a cave takes, as well as its position in the landscape, results from the dominant initial porosity present in the host rock and the mode of recharge to the limestone mass during speleogenesis (Palmer, 1991). For most caves, dominant rock porosity is in the form of discontinuities (joints, bedding planes) that serve as a template upon which cave growth occurs. Consequently, for relict caves the morphology of the passages, along with other information, can be used to infer cave genesis and to also shed light upon paleohydrologic conditions. Cave passages developed along joints tend to be straight or angular and passages developed along bedding planes tend to be sinuous. If a cave system is composed predominantly of one of these passage types, then the overall cave may be categorized as joint-controlled or bedding-plane controlled (White 1988, p. 69). Stemming from these come two major cave conduit topologies: branchworks and mazes.
Branchwork caves (Fig. 1) are distinguished by stream passages that connect and merge into larger, fewer passages. The conduit arrangement mimics the behavior of surface streams, except that they are underground. Their passages usually do not branch out downstream, and few closed loops exist. Those loops that do form develop by sequential diversion to lower levels of the cave, where they merge with original passages farther downstream.

A maze cave is defined as one whose passages contain many closed loops that form simultaneously. One type is an anastomotic maze (Fig. 1), which is composed of curving tubes that intersect one another and form many closed loops to create the appearance of being braided. They are formed by regular floodwaters that are supplied by sinking streams or by water fed through a karst surface of bare bedrock. Whereas anastomotic caves have curving tubes and form braided patterns, network maze caves have very angular intersections and make a grid-like pattern. They can be formed various ways, for example 


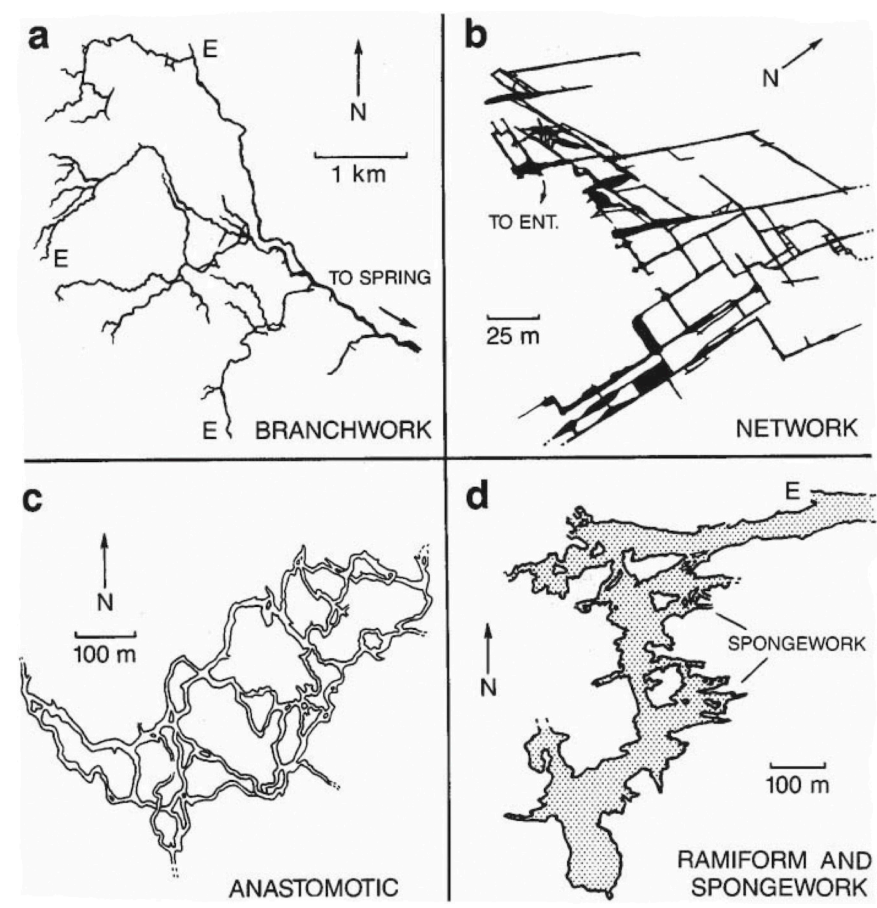

Fig. 1. Illustration of common patterns for dissolution caves (Palmer, 2007, by permission).

by water seeping through overlying or underlying insoluble rock, regular flooding, waters with different chemistries mixing, or the oxidation of hydrogen sulfide producing sulfuric acid (Palmer, 1991).
We investigated a relict cave, Ohio Caverns, that is present within the Bellefontaine Upland area of the Interior Lowland physiographic province (ODNR 1998). This region is an interlobate outlier within the Till Plains of the Central Lowlands province of North America (Fig. 2, inset). Previous workers (Hills, 1916; Hoy, 1993; Hoy, et al., 1995; Brayman, 2002; Codispoti, 2011) have inferred a relationship between the cave and glacial activity, as reflected in the chemical and clastic sediments found within the cave. Here, we examine the cave morphology for additional evidence of the influence of glacial activity. Preliminary comparison of overall cave pattern (Fig. 3) to Palmer's (2007) matrix (Fig. 1) does not show a clear match for genetic type. The present study seeks to identify the structural controls on development of this cave within the context of glacially overridden terrain.

With respect to nomenclature, it is probably correct that most "joint" controlled cave passages throughout the world are formed along mode-1 (tensile, opening) fractures, which are properly termed "joints". These form nearly vertically, and normal to horizontal bedding. Such cave passages are linear in map view, or angular if they make use of multiple joint directions. For clarity within this paper we will use the term "fracture" when the mode of origin for a discontinuity is unclear.

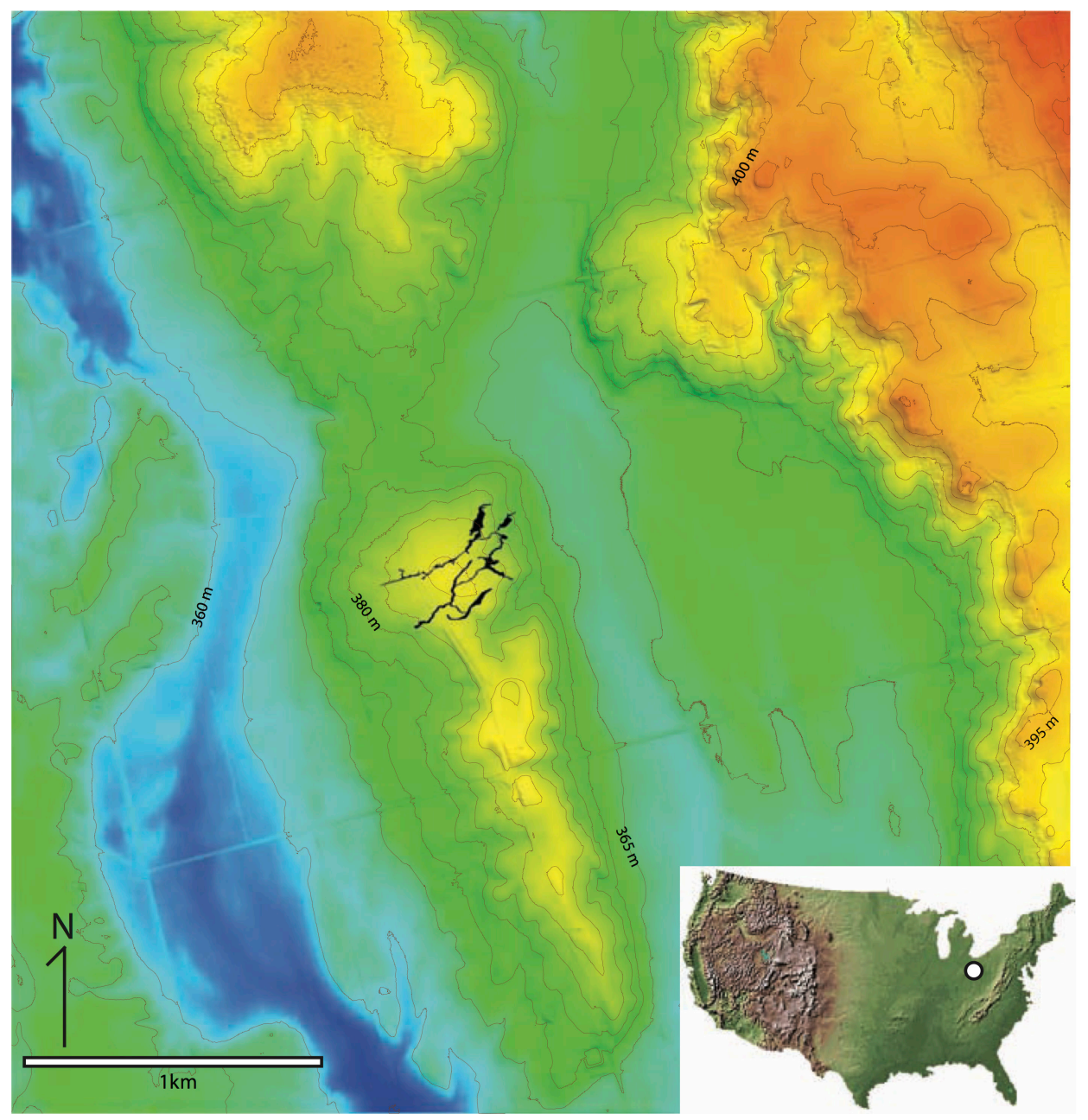

Fig. 2. Detail of topography in region of Mt. Tabor and Ohio Caverns. Inset white dot shows location within United States. Topography derived from LIDAR data supplied by Ohio Geographically Referenced Information Program. Contour interval is $5 \mathrm{~m}$. Ohio Caverns is shown as irregular black lines near center of figure. 


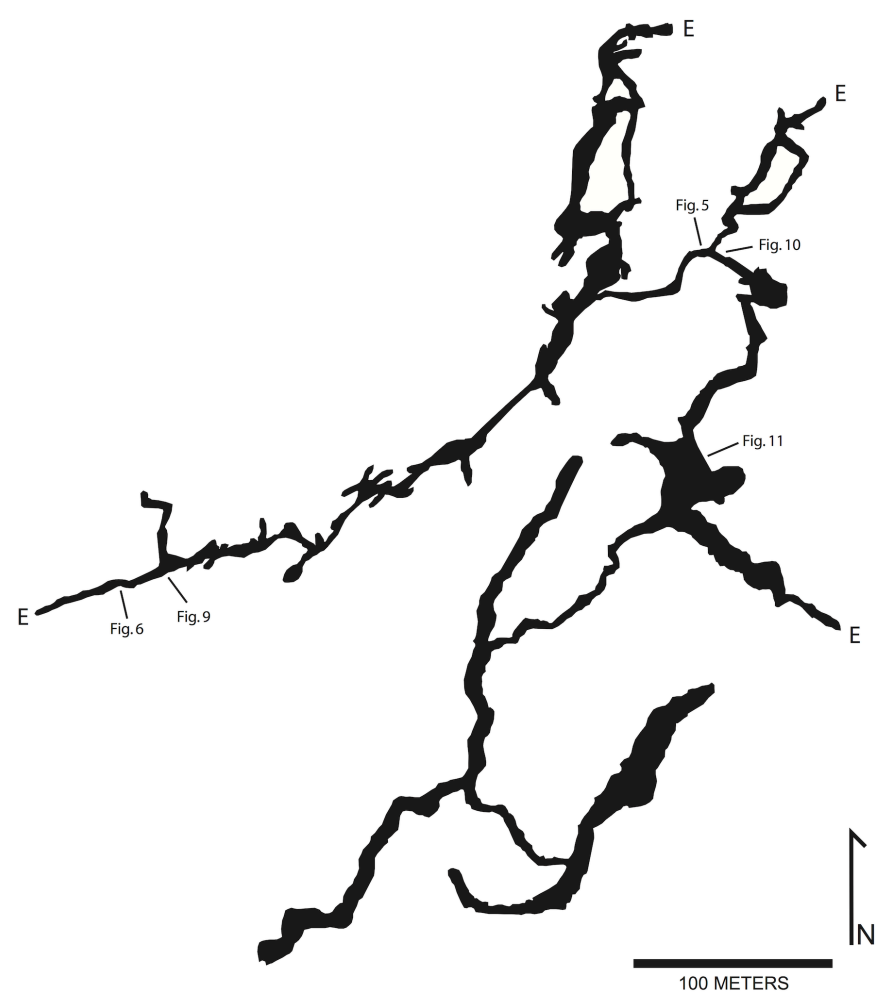

Fig. 3. Outline map of Ohio Caverns, redrafted from Ohio Caverns (2013). There are likely many unexplored passages that remain filled with sediment and are not shown on map. "E" indicates entrance to cave.

There has long been discussion in the literature as to the effects of glaciation on karst (e.g., Ford et al. 1983; Ford \& Williams, 2007; Smart, 2004), and the ways in which earlier karst landforms may "survive" glaciation. Recent work (Cooper 2014; Cooper \& Mylroie 2014, 2015; Faulkner, 2007, 2010) using morphometric, hydrologic, and other approaches has shown that caves may form earlier, or may form post glaciation. Localized conditions are very important (Mylroie, 1984). Sediment infilling is common.

Many caves in alpine settings have been affected by glaciation, and have been studied with regard to their genesis (e.g., Hauselmann, 2002). These steep terrain settings generate classical stair-step shaft-andgallery morphologies. Less commonly examined are those caves that have been impacted by continental glaciation. Castleguard Cave (Alberta, Canada), part of which lies under the Columbia Icefields, may serve as a potential analog. It has been the subject of extensive hydrologic and geologic study (Ford, et al., 1983; Smart, 1983). Seasonal flooding due to melting shifts the cave from a vadose to phreatic state annually. In New York State there is extensive cave development in the flat-lying Helderberg Limestone, and evidence of past glaciation in the form of sediments is seen in some caves (Palmer et al., 1991; Cooper \& Mylroie, 2015). Changes in drainage due to removal of ice-blockage are also recognized in these karst systems (Palmer et al., 1991). A generalized linkage between circum-glacial sedimentation and paragenetic (upward) growth of cave passages has been observed from many locations (Farrant \& Smart, 2011). The effects of ice margin hydrology have also been indicated as speleogenetic factors (Murphy et al., 2015).
Overall, the genesis of caves formed in circumglacial conditions is one of substantial complexity. This results from polyphase growth, extremely variable hydraulic gradients, changing boundary conditions, and possible mechanical effects of icecontact. The present study adds to the body of knowledge by investigating the structural controls on cave development in an isolated knob that has been overridden multiple times (Quinn \& Goldthwait, 1979) by continental glaciation. The two competing hypotheses being evaluated are: a) The cave has formed along regionally oriented tectonic fractures, and $b)$ the cave has formed along fractures that are of local, possibly glaciogenic, origin.

\section{STUDY SITE AND REVIEW OF PROBLEM}

Ohio Caverns (Fig. 3) is an extensive, mostly horizontal, multi-conduit cave system formed in the Devonian Columbus Limestone, Champaign County, Ohio. This area is on the eastern limb of the Cincinnati Arch, with rocks having a $<1^{\circ} \operatorname{dip}$ (Stout et al., 1943). The cave has a mapped length of over $1.5 \mathrm{~km}$, an elevation of 390 meters, and is located at North $40.24^{\circ}$ West $83.70^{\circ}$. This landmark has been known and open to the public for many years (Hills, 1916; White, 1926). Numerous maps of the cave have been prepared (Hills, 1916; Richey, 1921, White, 1926; Grissom, 1997; Ohio Caverns, 2013), though none can be considered a complete representation of the karst system because many sediment plugged (unexcavated) conduits are present and therefore unmapped.

The cave is located in an area of gentle relief. The bedrock knob (Mt. Tabor) in which the cave is found rises $30 \mathrm{~m}$ above broad valleys infilled with glacial outwash. A thin capping of till and Devonian Ohio Shale are present above the limestone on Mt. Tabor (Fig. 4). Glaciers have overridden the knob under which Ohio Caverns lies at least twice in the past (Quinn \& Goldthwait, 1979). About 19,000 years ago, a thinner sheet of ice split at Mt. Tabor, creating the Scioto Sublobe and Miami Sublobe (Quinn \& Goldthwait, 1979).

The shale/limestone contact is exposed at the northeastern entrance to the cave (recently excavated) and is irregular. Observed conduit (passage) development is focused along a single bedding plane, although some lower level passages, mostly sediment filled, are known. Many of the passages in the main level were almost completely filled by sediment, which was excavated during development of trails in the cave for visitors. Individual conduit profiles are cross- or keyhole-shaped, with enlargement along the horizontal bedding plane as well as upward and downward into fractures (Figs. 5, 6). The keyhole morphology suggests initial formation under phreatic conditions, with subsequent lowering of the water table and vadose incision. The scallop studies of Brayman (2002) show that flow was primarily from east to west, and he determined a velocity of about $1 \mathrm{~cm} / \mathrm{s}$. Lower portions of the cross-section are filled with $6 \mathrm{~m}$ or more of clastic sediments (Brayman, 2002). 


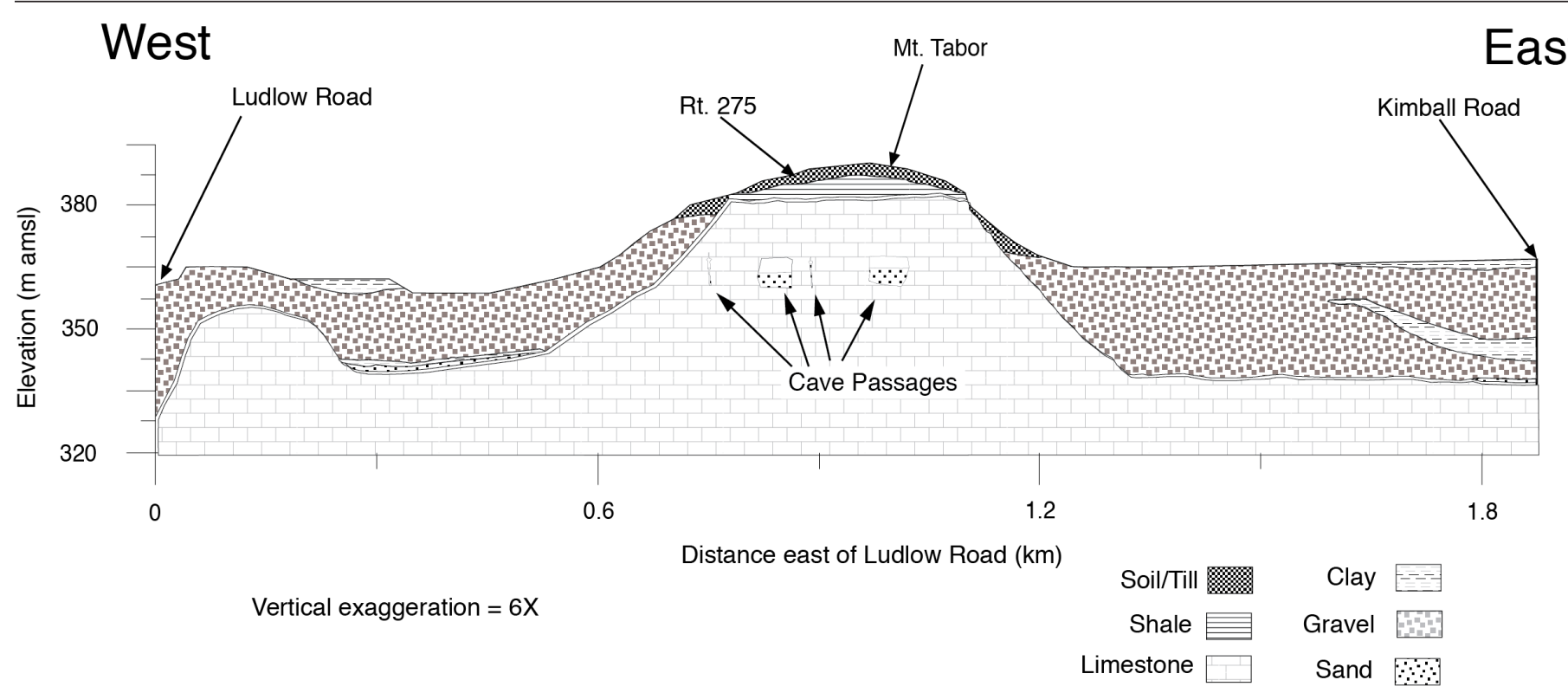

Fig. 4. Generalized cross-section (modified from Brayman, 2002), looking north, through Mt. Tabor and sediment filled valleys flanking hill. Interpreted from data obtained from ODNR well logs and drilling reports. Approximate position of cave shown.

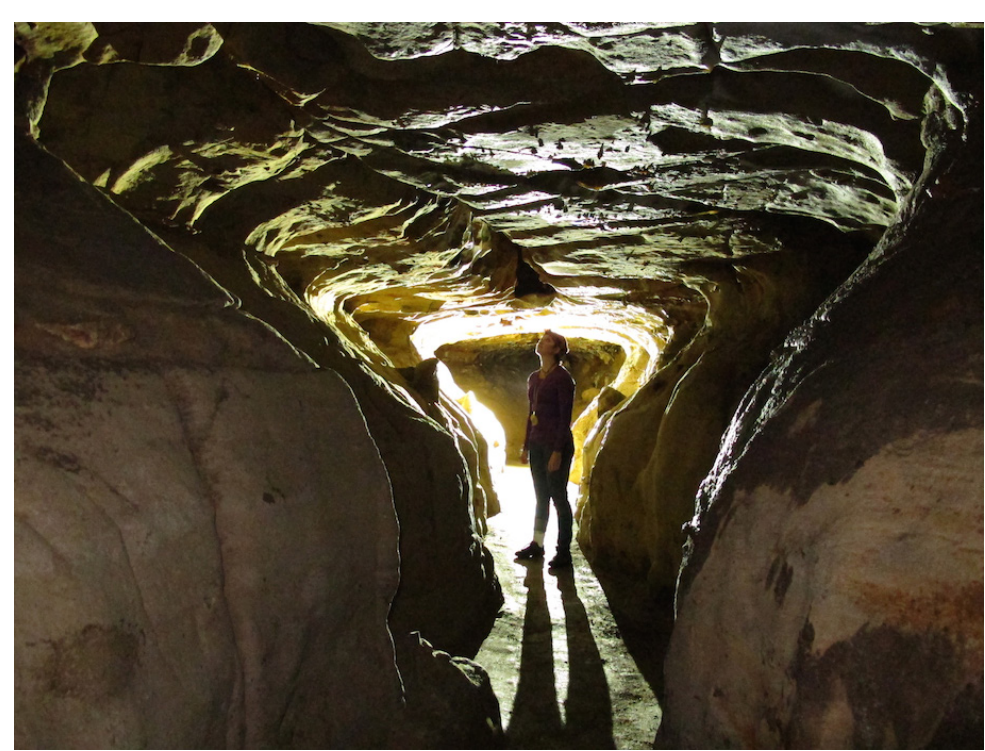

Fig. 5. Typical keyhole shaped passage in Ohio Caverns, showing enlargement along bedding plane. Note pervasive fracturing in ceiling. See Fig. 3 for location.

The precise age of the cave is not known, though some attempts at dating have been made. The cave is noted for its speleothems, which vary from dark red (earliest phase) to pure white (latest phase). The red speleothems are small, mostly microgour coatings. The white may commonly be $0.5 \mathrm{~m}$ in length, and at least one stalactite exceeds $1 \mathrm{~m}$ (the "Crystal King"). No dating of speleothems has been permitted.

Clastic sediment dating usually provides an age estimate closest to the age of the growth of the cave, but must be considered a minimum (Sasowsky, 1998). The clastic sediments have been examined by Hoy (1993), Brayman (2002), and Codispoti (2011). Hoy (1993) compared the cave sediment characteristics to those of the nearby glacial till, and concluded that they were similar overall, but that the cave sediments had been water lain. He ruled out limestone insoluble residue as a source. Brayman (2002) collected samples from "Mother-in-law-hole/Overlook Hole" in the cave, and identified 5 phases of fluvial deposition in a $5+\mathrm{m}$ section. Sediment texture varied from clay to sand, with minor larger clasts. The sand size fraction was dominated by carbonates, but had up to $50 \%$ sedimentary rock clasts and even up to $100 \%$ igneous rock clasts. He also determined that all were laid down in a normal magnetic chron. Because the cave is at the same elevation as current base level (adjacent valley floor), it is highly likely that the cave fill was deposited in Chron 1n (Brunhes), Middle to Late Quaternary, $<780 \mathrm{ka}$.

Codispoti (2011) performed a limited analysis of 3 small sediment samples from the same location. Her attempt to use carbon dating was not successful,

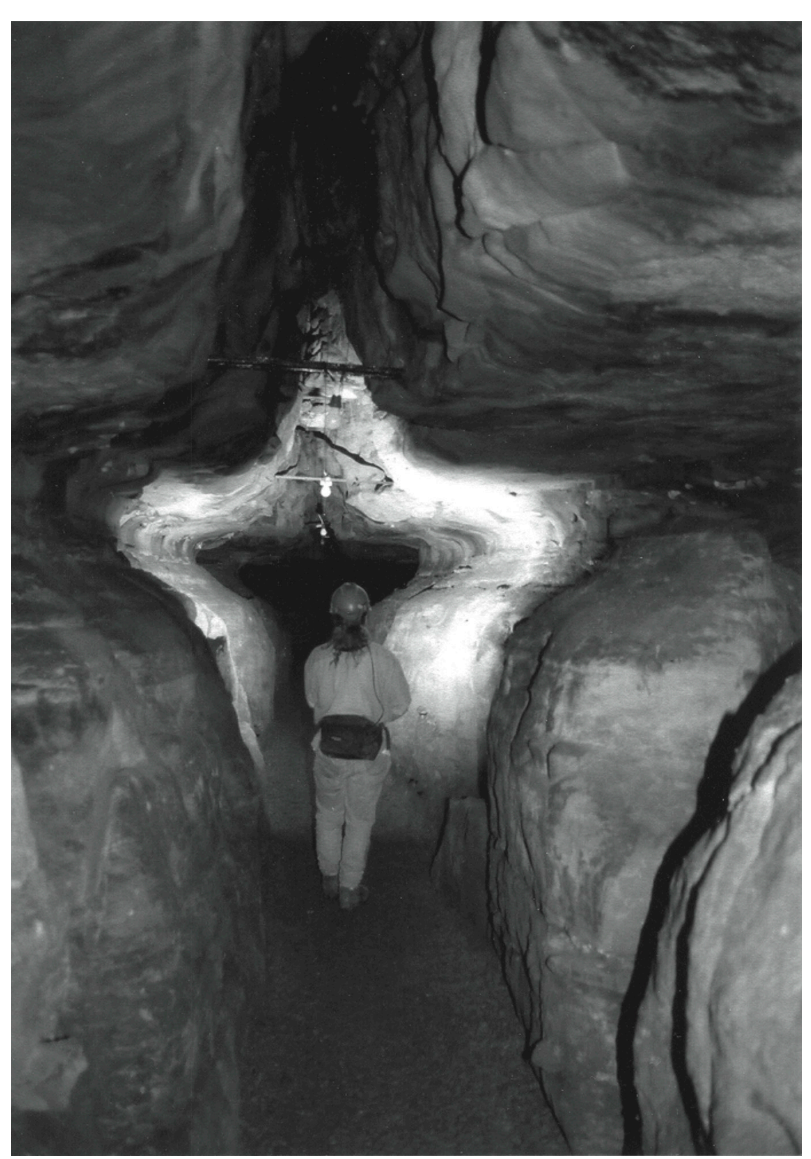

Fig. 6. Plus-sign shaped passage, illustrating enlargement along near vertical fracture and bedding plane. See Fig. 3 for location. 
because the sediments contained negligible organic matter. Likewise, no significant pollen was identified.

Two studies have examined the structural features or controls with respect to the cave. Hills (1916) noted the apparent effect of joints for localized passage segments (i.e., that the segments seem to follow joints). Codispoti (2011) was mainly concerned with speleothem deposition in the cave, but made a broad survey $(n=62)$ of all joints in the part of the cave open to the public. The fractures measured by Codispoti show a dominant joint direction of $\mathrm{N}-\mathrm{NW}$ and a secondary of NE (Fig. 7A). She concluded that these joint directions are a combined result of continental collisions during the Paleozoic and current stress regimes. She attributed the $\mathrm{NE}$ jointing that she measured in the cave to Paleozoic tectonism, whereas the NW jointing was attributed to regional erosional unroofing from the modern stress regime.

\section{METHODS}

The goal of the research was to test the hypotheses mentioned in the introduction by examining fractures that relate to conduit development in the cave. This was accomplished in 3 phases: 1) Compilation of a base map by merging existing cave surveys; 2) Observation/ measurement of the fracture orientations, morphology, and nature in the cave; 3) Analysis of data en-masse and in relation to position in the cave and in the landscape.

In order to focus on those fractures most important to cave forming process, we only measured fractures associated with main or side cave passage development. We refer to these as "conduit-significant fractures". This excluded many fractures that were present in the cave ceiling at a variety of orientations, but which did not show significant lateral (dissolutional) enlargement; these we refer to as "conduit-insignificant fractures".

Fracture strike was measured to within a few degrees accuracy by using tripod, laser pointers, Suunto compass, and Brunton pocket transit. A declination correction of $005.51^{\circ} \mathrm{W}$ was applied to orientation data collected in the field. If the fracture was clear on the cave ceiling, a person was positioned at a distance, and then the angle was shot towards them. In more difficult settings, a tripod upon which opposing red lasers were affixed was employed. The lasers were aligned with the fracture direction and the azimuth was measured on a straight part of the tripod head (aluminium). The southwestern branch is closed for conservation reasons by management, so no direct measurements or observations could be made there.

The cave survey data were extracted from a printed lineplot because the raw data were not available. The relationship of the cave to the landscape was analyzed by georeferencing the cave entrances to a topographic map created from Lidar data (via GlobalMapper v. 16). Azimuthal (rose plot) diagrams were created using Rockworks software.

\section{RESULTS}

To understand the structural controls on conduit development we examined and measured select fractures within the cave (Fig. 8) and compared them to conduit segments, local topographic aspect, and regional fracturing. We found that: 1) There were copious fractures but no predominant orientation existed; 2) The direction of fracturing varied between beds, as shown in peeled away sections of ceiling; 3) Passages in some beds did not seem to be controlled by a fracture, or were originally controlled by a fracture which had since been completely dissolved away; 4) Many of the "major" fractures which were controlling passages were very curvilinear; 5) No fresh joint faces were exposed-all had been dissolutionally weathered. Summary results can be seen in Fig. 7.
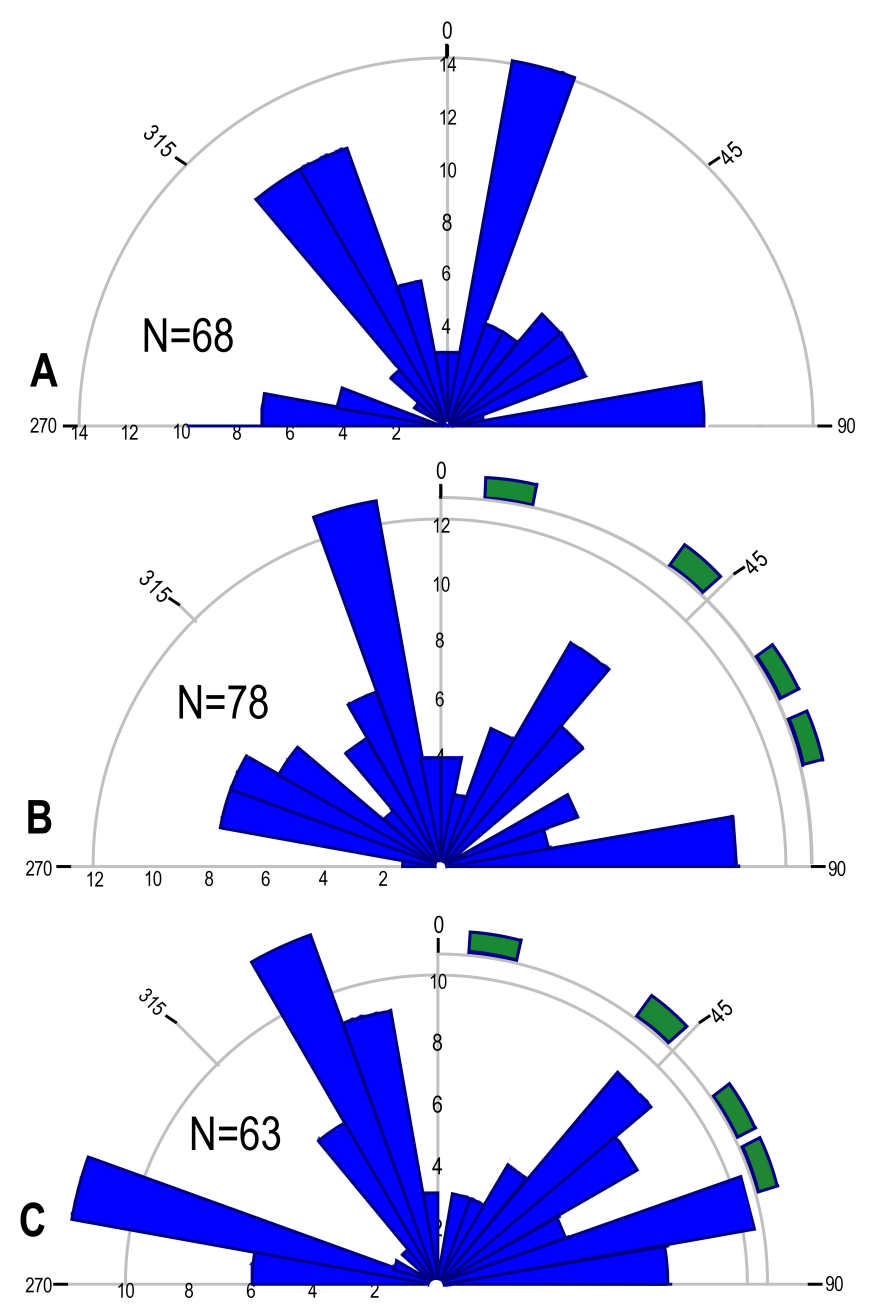

Fig. 7. Rose diagrams of fracture orientations for Ohio Caverns. A) Fracture orientations from Codispoti (2011); B) Cave survey shot orientations (from survey of Grissom); C) Conduit-significant fracture orientations from this study. Green sectors on margin show regional fracture data (Evans, 1994 and Ver Steeg, 1944). The southwestern branch is closed for conservation reasons by management, so no direct measurements or observations could be made there.

In the western section of the cave (Fig. 8) conduits follow joints more noticeably; this is expressed as straight passage segments having distinct enlarged joints in the ceiling. In the other sections there are many fractures, most of which do not serve as loci for conduit growth (i.e. they are not enlarged). Some passages that are quite linear show clear fracture control in the ceiling. Although some of these fractures are straight, many are curvilinear on a scale of tens of meters. Even though no fresh fracture faces are exposed, it was possible to examine the trace of the 


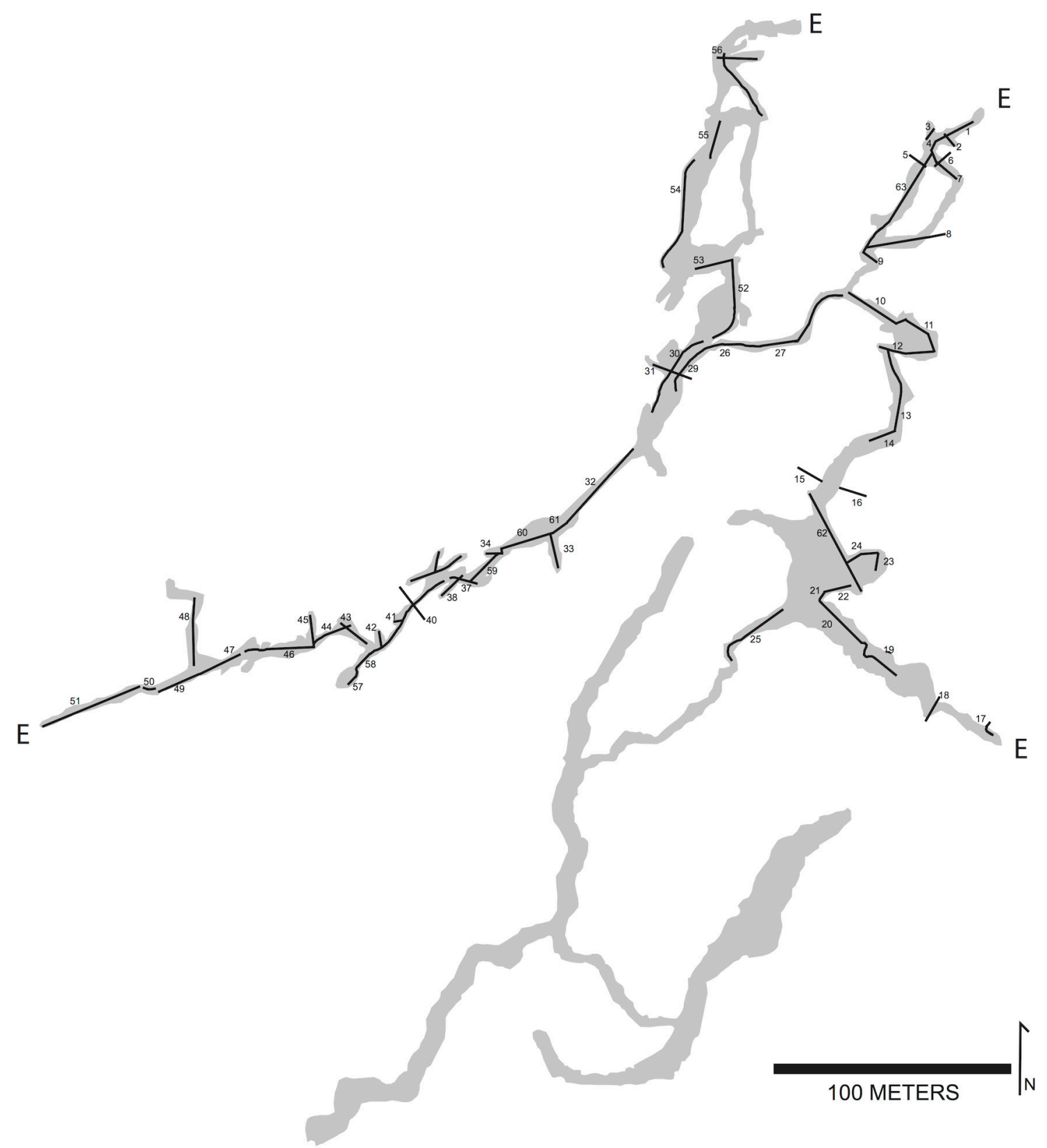

Fig. 8. Map of Ohio Caverns with conduit-significant fracture measurements from this study. Areas with no measurements were unavailable for this study. "E" indicates entrance to cave.

fractures along narrow ceiling apexes. Many of these exhibit a wavy/undulating form on a wavelength of 0.1 to $1 \mathrm{~m}$ (Figs. 9, 10). There are also passages that are straight in which no fractures are apparent in the ceiling. In some places, a thin bed (a few centimeters) is seen at ceiling level that does not have a fracture, but the overlying bed has a fracture that the conduit follows. There are also instances of en-echelon fracturing where the conduit seems to "shift" from one fracture to the other.

The comprehensive survey of conduit-significant fractures in the cave covered all portions of the cave that were open (Fig. 8). The data do not clearly reveal isolated dominant directions (Fig. 7C). The major direction class centers on 340 degrees, but there are substantial peaks at 045,075 , and also 285 . We also plotted cave survey data azimuths (Fig. 7B) to see if differences emerged between the 2 data sets. The cave survey data show a peak at 345 degrees, which correlates well with the 340 peak in conduitsignificant fracture orientations. The cave survey data also show lesser peaks at 035, 085, and 295 degrees, which have less compelling overlap with the joint data.

The data collected for the present study show no concordance with the fracture data (Fig. 7A) of Codispoti (2011). This is because the present work measured fractures associated with conduit enlargement, and Codispoti measured wall and ceiling joints throughout the cave, regardless of dissolutional enlargement. Therefore, her set includes the full range of discontinuities in the rock mass, as opposed to just those used in cave development.

\section{DISCUSSION}

The fractures observed in the cave could originate from a variety of conditions. However, the most likely causes to consider are:

i) Joints from regional (tectonic) stress fields

ii) Unloading (glacial or other)

iii) Stress relief (topographic) fracturing

iv) Glacial shear or other influences 


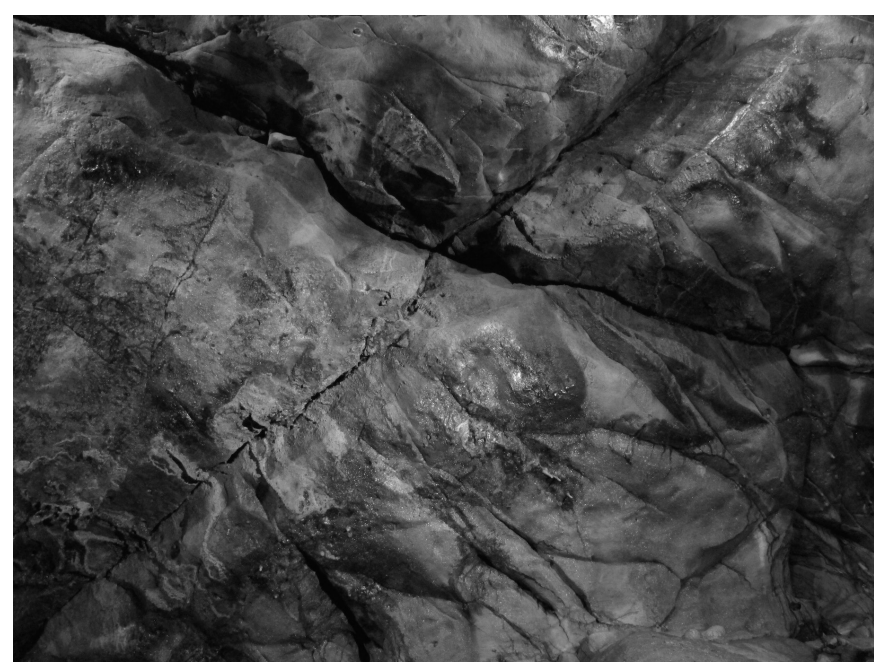

Fig. 9 .Photograph of undulating ceiling fracture. Field of view about $0.5 \mathrm{~m}$. See Fig. 3 for location.

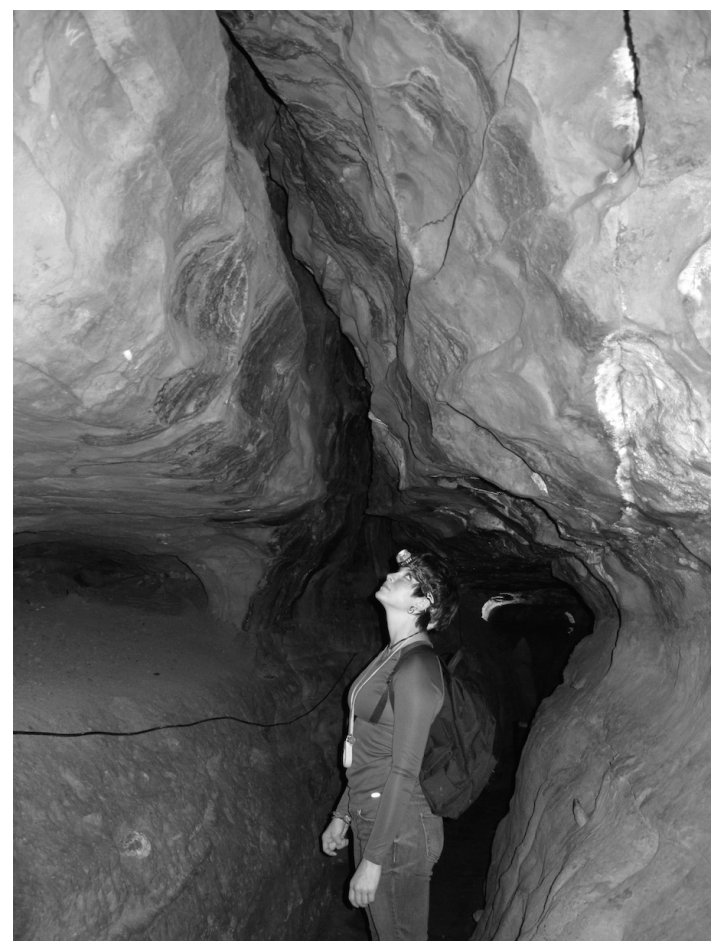

Fig. 10. Photograph of conduit-significant, slightly inclined undulating ceiling fracture, enlarged by dissolution. See Fig. 3 for location.

The four immediately following subsections explore the data in the context of these possible causes. The final discussion subsection synthesizes the origin of the cave in the context of the local geologic history.

\section{Joints from regional stress fields}

In many studies of caves, a clear relation between conduit orientation and regional joint sets is seen. Conjugate passage orientations, especially in maze caves, are strong indications of this. The Mt. Tabor area is in the Central Lowland physiographic province, and has not been subjected to extensive folding and faulting. But, it has been affected by wide field stresses related to the Alleghenian and other orogenies. The present state of stress in Ohio is reported (Evans, 1994) to result in joints with orientation 010 to 040 degrees. An additional regional trend for fractures in Ohio is 060 to 070 degrees (Ver Steeg, 1944) that Engelder (1982) indicates is the same orientation as the contemporary stress field. A cave that is truly controlled by regional joints will take on a network cave pattern in map view, will resemble a grid, and will have sharp, angular passage patterns (Fig. 1). In map view, Ohio Caverns does not exhibit the pattern of a network cave. Fractures created due to regional stresses are no doubt present in Mt. Tabor, but the conduit-significant data from Ohio Caverns do not show primary correlation with them (Fig. 7).

\section{Stress relief (topographic) fractures}

There are examples in the literature of caves following fractures that are not associated with regional stress fields. Along valleys in the Appalachian Plateau, there are many examples of valley parallel caves that make use of relatively young stress-relief fractures (Sasowsky and White, 1994). However, the relationship of overall cave passages of Ohio Caverns (Fig. 2) does not show such topographic concordance. If anything, the major passages of the cave seem to cut crosswise to the main valley walls.

\section{Unloading fractures}

The removal of overlying materials is recognized to produce surface parallel (unloading) fractures. The most well known unloading fractures are curved exfoliation features, usually in non-layered, homogeneous materials such as the granites of the Sierra Nevada batholith (e.g., Bahat et al., 1999) and other locations (e.g., Jahns, 1943). These have classically been ascribed to removal of confining stress, although recent work provides an alternative explanation involving near-surface compressive stresses (Martel, 2011). At Mt. Tabor, formerly overlying material could include both rock and glaciers. The effect of unloading has potential influence at Ohio Caverns due to the known factor of ice retreat. Additionally, unloading could potentially provide an explanation for the curved fractures that are seen in the cave. However, the orientation of the curved fractures in Mt. Tabor do not show concordance with the present day land surface, and in fact the map-view fractures seem to be curved in strike primarily, not in dip. Therefore, it does not seem feasible that unloading controls the morphology of the cave in map view.

It is possible, however, that the main bedding plane along which the cave formed has been "opened" by unloading. 0 to $30 \mathrm{~m}$ of rock overlies this plane, and it is quite likely that horizontal permeability along the plane would be enhanced by the reduced vertical stresses associated with deglaciation. This would control the vertical position along which the cave originated, but not the overall topology of the connections in map view.

\section{Glacially-related fractures}

Mt. Tabor has been overridden by ice at least twice, during MIS 6 and MIS 2 (Quinn \& Goldthwait, 1979; Szabo \& Chanda, 2004; Ehlers \& Gibbard, 2007). Clark et al. (1994) report maximum ice thicknesses of 250 to $500 \mathrm{~m}$ for this area of Ohio. This process undoubtedly exerted significant mechanical, hydraulic, and thermal stresses upon this relatively 
small rock mass. With an upland area of $1.18 \mathrm{~km}^{2}$, and hill volume above valley floor of $7.4 \times 10^{6} \mathrm{~m}^{3}$ (calculated from digital elevation model) all three effects may have been profound in the fractures they could produce. Both glacial and periglacial processes were in play.

Mechanical stresses include the loading and unloading by the ice sheets, as well as shear stresses and push imposed by the moving ice stream. Because the area is at the confluence of two lobes, we would also expect differential stresses through time as the various ice streams waxed and waned. The damaging effects of glacial stresses on bedrock are well known (Aber \& Ber, 2007). In fact, masses of rock larger than Mt. Tabor, called megablocks, frequently exhibit significant shearing and faulting caused by ice push (Aber \& Ber, 2007).

The forces of glacial movement upon underlying landscapes are well recognized in features such as drumlins, roches moutonnées, grooves, and so forth. During continental glaciations existing landscapes tend to be modified, but not obliterated. When the ice sheets overrode Mt. Tabor, it is easy to envision differential stresses being imposed on this topographic high as ice traversed the sides and top of the hill. Limits upon the possible shear stress are placed by the yield strength of ice, which is thought to be around $100 \mathrm{kPa}$ (Menzies, 1995). However, the actual stresses applied to the landscape depend upon many factors such as speed of movement of the ice, fluid conditions at the land-ice contact, sediment content of the basal ice, configuration of the flow, etc.

Basic thermal stress was also applied to the rock mass from cooling and heating on a variety of time scales. Rutqvist et al. (2008) found that 30\% of thermally induced fractures were random in direction, and this is accordant with the observed distribution of fractures. Additionally, freezing of water in the rock mass is a well-known cause of rock disintegration, as are other freezing related processes (i.e., Murton et al., 2006; Oberender \& Plan, 2015). Finally, the interaction of the solid rock with glacial meltwaters from valley margin streams or moulins could potentially open up pathways in essence by "hydrofracturing".

\section{Synthesis of cave origin and controls}

Glaciation of this region has resulted in significant changes to surface and groundwater flow systems. These changes are important to consider in the context of cave development. The area is presently drained by the southwest flowing Mad River, a tributary of the Ohio River that lies only a few $\mathrm{km}$ west of Ohio Caverns. Prior to $2 \mathrm{Ma}$, an ancestral Mad River served as local base level, draining to the pre-glacial Teays River, which flowed westward through central Ohio (Norris \& Spicer, 1958; Melhorn \& Kempton, 1991). This preglacial river was deeply incised.
The present day course of the Mad River follows this now "buried" valley that holds up to 100 meters of glacio-alluvial fill. In terms of groundwater flow, Codispoti (2011) hypothesized that the local change in base level caused by the valley filling could have profoundly affected groundwater flow paths, and consequently cave development might have initially occurred along steeper gradients that were present $>$ $2 \mathrm{Ma}$. This is possible, but the lower parts of the cave are completely filled by sediments at present, and so nothing is known of their topology and character. The currently traversable extent of the cave is almost exclusively horizontal, and at grade with the current valley floor. This supports the concept that the portion of the cave we see is genetically related to hydrologic regimes associated with the latest stages of glaciation and retreat.

The characteristics of the cave sediment infill support that the sediment is derived from adjacent drift, and that they were water transported. There is not, however, sufficient evidence to determine the age or specific linkage to surface events. The simplest interpretation would emplace the sediments at or near the same time as the valley fill deposits that surround Mt. Tabor. The valley fill directly adjacent consists of sand and gravel of Wisconsinan age (Pavey et al., 2013), but there are also tills interbedded with sand and gravel not far away. This sedimentation episode would have likely been during the Wisconsinan retreat $20 \mathrm{ka}$ to $13 \mathrm{ka}$, but it is also probable that the cave sediments significantly post-date the main phase of speleogenesis. This is indicated by the substantial thickness of fill that is present, suggesting a "backing up" of existing relatively tall passages.

With regard to structural controls, the overall rock mass hosting the cave is fractured in many directions and with varying fracture density. The pervasively fractured ceiling (Fig. 11) is suggestive of some carbonate units in the Appalachians. For example the Elbrook Fm. (Cambrian) and Newala Fm.

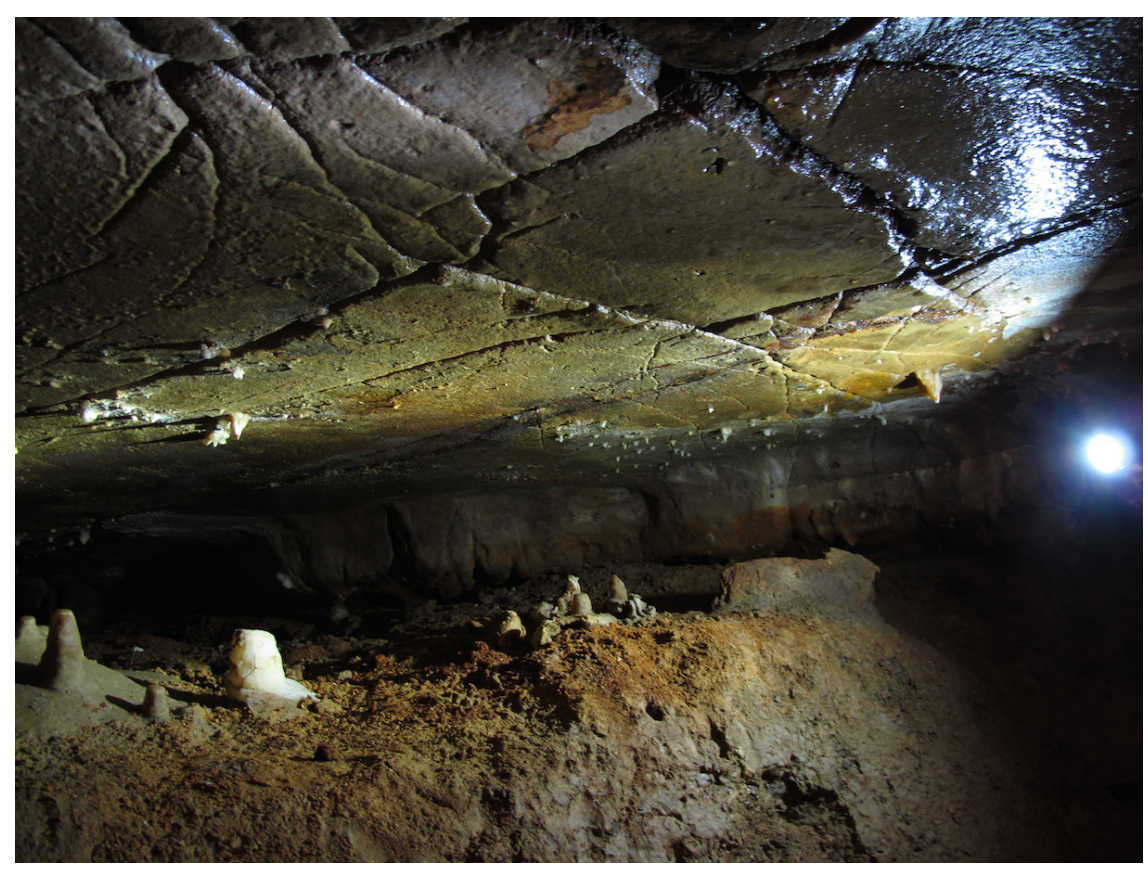

Fig. 11. Photograph of cave ceiling illustrating multiple non-conduit-significant fracture directions on exposed bedding plane. See Fig. 3 for location. 
(Ordovician; Feder, 1964) exhibit an extremely fractured nature, which expresses as a "butcherblock" pattern (Waynesboro Fm., Ordovician; Rader $\&$ Henika, 1978). This has been attributed to multiple stress fields throughout the lifetime of the units. However, the study area is far to the west, and would not be expected to suffer the same level of stresses as found closer to the orogen.

In the case of Ohio Caverns, it appears that the controlling fractures in map view may not be joints sensu stricto, but rather some combination of tensile and shear (mode-1 and mode-2) fractures, probably forming in the regime transition between tensile and shear fracturing. This is easy to envision in a situation with ice advancing over this topographic asperity, and would result in the curved fractures which are observed in many places in the cave. It can also explain the numerous fracture directions.

\section{CONCLUSIONS}

Conduit growth in Ohio Caverns made use of nearvertical fractures and a bedding plane as an initial template for development. However, the fractures so used do not match orientations expected from regional stress fields. The highly fractured nature of the rock indicates changing stresses that were applied tectonically, topographically, and glacially. Most of the fractures are curved and wavy, indicating anisotropy of stress or material properties. The curved fractures are likely related to stresses induced by glacial override of this small knob. Such curved joints do not develop in all glaciated limestone areas. For example, in Schoharie County, New York, many caves are developed along systematic or localized valleyparallel stress relief joints (Cooper \& Mylroie, 2015). But, Ohio Caverns formed in a relatively unique setting where a small limestone knob has been overridden by a continental glacier. This setting appears to have generated a unusual structural template upon which speleogenesis could occur.

The presence of numerous fracture directions at Ohio Caverns suggests that the cave could have formed in virtually any direction, and the measured conduit directions (Fig. 7B) support this; there is no preferred orientation. The specific fractures upon which conduit development did occur appears to have been controlled by the paleohydrology of the site, because water being driven from areas of higher head to areas of lower head would follow the path of least resistance within the carbonate mass.

Normally, the regional stress regime affects the development of passages due to systematic fracturing. However, in map view it is clear that Ohio Caverns does not match the regional pattern well enough to consider it to be a template for the development of the cave. Likewise, Ohio Caverns cuts across topography, so it does not appear to be developed along topographically controlled stress-relief fractures. Furthermore, it is evident from inside the cave that the passages themselves are fracture-controlled due to their development along the near-vertical fracture planes. Overall, the cave is relatively confined to one bedding plane parting, but passage directions are influenced by the near-vertical fracturing in the cave.

The knob was most certainly subjected to unloading and stress relief during times of glacial movement and retreat. We interpret that this, along with the fact that the glaciers sliding over it were applying shear, caused the fractures to straddle the boundary between modes 1 and 2 . The pattern shown by the relict cave today reflects a long and complex structural and hydrologic history. It also demonstrates a new class of discontinuities, albeit rare, that can serve as a basis for cave development.

Although available data do not allow firm correlation of the speleogenetic history to glacial and interglacial events, we can make some educated inferences. Pre-Illinoian (MIS 22+) drift deposits are not known directly from this area, but are known to the south along the Ohio River. So, initial override of Mt. Tabor by ice during this time is possible (circa $1 \mathrm{Ma}$ ). Ice override certainly occurred during the Wisconsinan and Illinoian (MIS $2 \& 6$ ) Stages, based upon the maximum extents of glaciation (terminal moraines, Szabo et al., 2011). So, it is possible that Mt. Tabor has been subjected to 3 episodes of glacial override, and the accompanying stresses discussed earlier in the paper. Working backwards in time from present, the sedimentary fills in the cave are similar to, and at approximately the same elevation as, the Wisconsinan drift in the adjacent valleys. This implies that sedimentation occurred during Wisconsinan deglaciation, and that the cave probably initiated during one of the earlier interglacials. The timing for the formation of the joints is less clear. They could have formed during any of the earlier glacial stages. Given the size of the passages and declining base level implied by the phreatic/vadose transition expressed in passage morphology, it is likely that the structural template upon which the cave formed was in place by the end of the Illinoian Stage (MIS 6).

It would be useful in the future to compare the results of this study of Ohio Caverns to caves in similar topographic settings in other glaciated regions with similar rock types, and to caves in non-glaciated regions. This would allow a more definitive linkage between the observed features and the glacial history. The viability of the fracturing mechanism could be further tested by finite element modeling of the rock response to ice-generated stresses, though definition of robust boundary conditions is not simple.

\section{ACKNOWLEDGEMENTS}

The staff of Ohio Caverns were integral to the field work, and we thank them for their assistance. In particular we thank Tim Grissom for his help and thoughtful discussion. Chris Connors (Washington and Lee University) and W. Ashley Griffith (University of Texas at Arlington) provided very helpful insight on structural and mechanical considerations. Thanks also to Horton Hobbs III, Erin Hazelton, Gina Filiano and Lauren Fissel for their assistance. The insightful comments of 3 anonymous reviewers were very useful and are gratefully acknowledged. 


\section{REFERENCES CITED}

Aber J.S. \& Ber A., 2007 - Glaciotectonism. Developments in Quaternary Sciences, v. 6: Elsevier, Amsterdam, 246 p.

Bahat D., Grossenbacher K. \& Karasaki K., 1999 Mechanism of exfoliation joint formation in granitic rocks, Yosemite National Park. Journal of Structural Geology, 21: 85-96.

http://dx.doi.org/10.1016/S0191-8141(98)00069-8

Brayman A.G., 2002 - The sedimentology and paleohydrology of Ohio Caverns, Champaign County, Ohio. MS Thesis, The University of Akron, 164 p.

Clark J.A., Hendriks M., Timmermans T.J., Struck C. \& Hilverda K.J., 1994 - Glacial isostatic deformation of the Great Lakes region. Geological Society of America Bulletin, 106: 19-31.

http://dx.doi.org/10.1130/0016-7606(1994)106 $<0019$ :GIDOTG $>2.3 . \mathrm{CO} ; 2$

Codispoti J.E., 2011 - Speleothem genesis in Ohio Caverns: how erosion of overlying strata sesulted in different speleothem characteristics. MS Thesis, Ohio State University, 289 p.

Cooper M., 2014 -Verification of post-glacial speleogenesis and the origins of epigene maze caves in New York. MS Thesis, Mississippi State University, 173 p.

Cooper M. \& Mylroie J.E., 2014 - Post-glacial speleogenesis: Verification of a hypothetical model, and origins of maze caves in glaciated terrain. Cave and Karst Science, 41: 84-95.

Cooper M. \& Mylroie J.E., 2015 - Glaciation and speleogenesis: Interpretations from the Northeastern United States. Springer, Heidelberg, 142 p. http://dx.doi.org/10.1007/978-3-319-16534-9

Ehlers J. \& Gibbard P. L., 2007 - Glaciations: Overview, in Elias, S. A., ed., Encyclopedia of Quaternary Science, v. 2: Amsterdam, Elsevier, 1023-1031 p.

Engelder T., 1982 - Is there a genetic relationship between selected regional joints and contemporary stress within the lithosphere of North America? Tectonics, 1: 161-177 p.

Evans M.A., 1994 - Joints and decollement zones in Middle Devonian shales: Evidence for multiple deformation events in the central Appalachian Plateau. Geological Society of America Bulletin, 106: 447-460. http://dx.doi.org/10.1130/0016-7606(1994)106 $<0447$ :JADCZI $>2.3 . \mathrm{CO} ; 2$

Farrant A.R. \& Smart P.L., 2011 - Role of sediment in speleogenesis; sedimentation and paragenesis. Geomorphology, 134: 79-93.

http://dx.doi.org/10.1016/j.geomorph.2011.06.006

Faulkner T., 2007. The top-down, middle-outwards, model of cave development in central Scandinavian marbles. Cave and Karst Science, 34: 3-16.

Faulkner T., 2010. An external model of speleogenesis during Quaternary glacial cycles in the marbles of Central Scandinavia. Cave and Karst Science, 37: 79-92.

Feder G.L., 1964 - Cause of hatchured weathering patterns produced on dolomite. Journal of Sedimentary Petrology, 34: 197-198.

http://dx.doi.org/10.1306/74D71019-2B21-11D78648000102C1865D

Ford D.C., Smart P.L. \& Ewers R.O., 1983 - The physiography and speleogenesis of Castleguard Cave, Columbia Icefields, Alberta, Canada. Arctic and Alpine Research, 15: 437-450.

http://dx.doi.org/10.2307/1551231

Ford D.C. \& Williams P.W. 2007 - Karst hydrogeology and geomorphology. Chichester, Wiley, $562 \mathrm{p}$.

http://dx.doi.org/10.1002/9781118684986
Grissom T., 1997 - Unpublished lineplot map of Ohio Caverns: Unknown scale, 1 sheet, $8.5 \times 11$ inches.

Hauselmann P., 2002 - Cave genesis and its relationship to surface processes: Investigations on the Seibenhengste region (BE, Switzerland). Hohlenforschergemeinschft Region Hohgant HRH, 168 p.

Hills T.M., 1916 - Reames Cave. Ohio Journal of Science, 16: 209-215.

Hoy R.G., 1993 - The origin of fine-grained sediments in the Ohio Caverns. Honors Thesis, Kent State University, $32 \mathrm{p}$.

Hoy R., Harbor J. \& Carlson E., 1995 - Origin of the finegrained sediments in the Ohio Caverns. Northeastern Geology, 17: 83-88.

Jahns R.H., 1943 - Sheet structure in granites: Its origin and use as a measure of glacial erosion in New England. Journal of Geology, 53: 71-98. http://dx.doi.org/10.1086/625130

Martel S.J., 2011 - Mechanics of curved surfaces, with application to surface-parallel cracks. Geophysical Research Letters, 38: L20303. http://dx.doi.org/10.1029/2011GL049354

Melhorn W.N. \& Kempton J.P., 1991 - Geology and hydrogeology of the Teays-Mahomet bedrock valley system. Boulder, Geological Society of America Special Paper: 258, 128 p.

Menzies J., 1995 - The dynamics of ice flow. In: Menzies J. (Ed.), Modern glacial environments: Processes, dynamics and sediments. Butterwort-Heinemann Ltd., Oxford, 139-196.

Murphy P.J., Faulkner T.L., Lord T.C. \& Thorp J.A., 2015 - The caves of Giggleswick Scar - Examples of deglacial speleogenesis? Cave and Karst Science, 42: 42-53.

Murton J.B., Peterson R. \& Ozouf J.-C., 2006 - Bedrock fracture by ice segregation in cold regions. Science, 314: 1127-1129.

http://dx.doi.org/10.1126/science. 1132127

Mylroie J.E., 1984 - Pleistocene climatic variation and cave development. Norsk Geografisk Tidsskrift, 38: 151-156. http://dx.doi.org/10.1080/00291958408552119

Norris S.E. \& Spicer H.C., 1958 - Geological and geophysical study of the preglacial Teays valley in West-central Ohio. United States Geological Survey Water-Supply Paper 1460-E: 232 p.

Oberender P. \& Plan L., 2015 - Cave development by frost weathering. Geomorphology, 229: 73-84. http://dx.doi.org/10.1016/j.geomorph.2014.07.031

Ohio Caverns, 2013 - Map of Ohio Caverns. 1 p. digital file, no scale. http://www.ohiocaverns.com/ Surveyedmap.pdf

Palmer A.N., 1991 - Origin and morphology of limestone caves: Geological Society of America Bulletin, 103: 1-21. http://dx.doi.org/10.1130/0016-7606(1991)103 $\leq 0001$ :OAMOLC $>2.3$.CO;2

Palmer A.N., 2007 - Cave geology. Cave Books, Dayton, Ohio, $454 \mathrm{p}$.

Palmer A.N., Palmer M.V., Porter C.O., Rubin P.A. \& Mylroie J.E., 1991 - A geologic guide to the karst and caves of the Helderberg Mountains, Schoharie, and Albany Counties, New York. In: Nardacci M. (Ed.), Guide to the caves of the Northeast. Guidebook to the National Speleological Society Annual Convention. Huntsville, Alabama, National Speleological Society, 105-167.

Pavey R.R., Aden D.J., Fugitt F.L., Jones D.M. \& Angle M.P., 2013 - Surficial geology of the Bellfeontaine 30 $x 60$ minute quadrangle. Ohio Department of Natural Resources, Division of Geological Survey Map SG-2 Bell, scale 1:100,000.

Quinn M.J. \& Goldthwait R.P., 1979 - Glacial geology of Champaign County, Ohio. State of Ohio Department of Natural Resources Division of Geological Survey. Report of Investigations no. 111, 17 p. 
Rader E.K. \& Henika W.S., 1978 - Ordovician shelf-to basin transition. In: Contributions to Virginia Geology III, Virginia Division of Mineral Resources Publication 7, 91-97.

Richey C.M., 1921 - Map of Ohio Caverns: Virginia Military Survey, scale 30': 1", 1 sheet.

Rutqvist J., Freifeld B., Min K.B., Elsworth D. \& Tsang Y., 2008 - Analysis of thermally induced changes in fractured rock permeability during 8 years of heating and cooling at the Yucca Mountain Drift Scale Test. International Journal of Rock Mechanics and Mining Sciences, 45: 1373-1389.

http://dx.doi.org/10.1016/j.ijrmms.2008.01.016

Sasowsky I.D. \& White W.B., 1994 - The role of stress release fracturing in the development of cavernous porosity in carbonate aquifers. Water Resources Research, 30: 3523-3530.

http://dx.doi.org/10.1029/94WR01727

Sasowsky I,D., 1998 - Determining the age of what is not there. Science, 279 (5358): 1874.

http://dx.doi.org/10.1126/science.279.5358.1874

Smart C.C., 1983 - The hydrology of the Castleguard karst, Columbia Icefields, Alberta, Canada. Arctic and Alpine Research, 15 (4): 471-486.
Smart C.C., 2004 - Glacierized and glaciated karst. In: Gunn J. (Ed.), Encyclopedia of caves and karst science: Fitzroy Dearborn, New York, 388-390.

Stout W., Ver Steeg K., and Lamb G.F., 1943 - Geology of water in Ohio. Geological Survey of Ohio, $4^{\text {th }}$ Series, Bulletin 44: $694 \mathrm{p}$.

Szabo J.P. \& Chanda A., 2004 - Pleistocene glaciation of Ohio, U.S.A. In: Ehlers J. \& Gibbard P.L. (Eds.), Quaternary glaciations - extent and chronology: Part II. North America: Amsterdam, Elsevier, 233-236. http://dx.doi.org/10.1016/S1571-0866(04)80200-8

Szabo J.P. Angle M.P. \& Eddy A.M., 2011 - Pleistocene glaciation of Ohio, USA. In: Ehlers J., Gibbard P.L. \& Hughes P.D. (Eds.), Developments in Quaternary Science - Quaternary glaciations - extent and chronology - A closer look, v. 15: Amsterdam, Elsevier, 513-519. http://dx.doi.org/10.1016/B978-0-444-534477.00039-8

Ver Steeg K., 1944 - Some structural features of Ohio. Journal of Geology. 52: 131-138. http://dx.doi.org/10.1086/625199

White G.W. 1926 - The Limestone Caves and Caverns of Ohio. The Ohio Journal of Science. 26: 73-116.

White W.B., 1988 - Geomorphology and Hydrology of Karst Terrains. Oxford, Oxford University Press, 464 p. 